\title{
THE OPERATION OF AUTOMOBILE ENGINES ON BIOFUEL E85
}

\section{ADAM POLCAR}

Department of Engineering and Automobile Transport, Mendel University of Brno, Zemědělská 1, 61300 Brno, Czech Republic, Tel.: +420 545132 943, E-mail: adam.polcar@mendelu.cz

\section{ANTONÍN SKŘIVÁNEK}

Department of Engineering and Automobile Transport, Mendel University of Brno, Zemědělská 1, 61300 Brno, Czech Republic, Tel.: +420 545132 943, E-mail: antonin.skrivanek@mendelu.cz

\section{JIŘí ČUPERA}

Department of Engineering and Automobile Transport, Mendel University of Brno, Zemědělská 1, 61300 Brno, Czech Republic, Tel.: +420 545132 129, E-mail: jiri.cupera@mendelu.cz

\section{SHRNUTÍ}

Článek se zabývá monitorováním výstupních parametrů automobilových motorů při provozování na biopalivo E85 s Pro analýzu byla vybrána dvě vozidla a jeden motor. Měření vozidel bylo provedeno pomocí válcového dynamometru na vozidlové zkušebně. Motor byl testován na zkušebně motorů pomocí vírivého dynamometru. Jako referenční palivo byl zvolen benzín Natural 95 (BA95). Vozidla byla pro spalování E85 vybavena dodatečnými prestavbovými sadami. Seřizení motoru proběhlo pomocí programovatelné řídicí jednotky. Všechna měření probíhala při ustálených parametrech. Mezi hodnocené parametry patřila spotřeba motoru, výkon a efektivní účinnost. Výsledky měření poukazují na pozitivní vliv etanolu na spalovací proces u všech hodnocených motorů. Jak je z výsledku dále patrné má majoritní vliv na změnu výstupních parametrů i seřízení motoru resp. vstřikované dávky.

KLÍČOVÁ SLOVA: STECHIOMETRICKÝ POMĚR, SPOTŘEBA PALIVA, VÝKON MOTORU, EFEKTIVNÍ ÚČCINNOST

\section{ABSTRACT}

This article deals with the monitoring of automobile engine output parameters when running on biofuel E85. Two vehicles and one engine were chosen for the analysis. Experimental measurements were performed on these vehicles using a chassis dynamometer. The engine was tested using an eddy current dynamometer at the engine test laboratory. Petrol type Natural 95 (BA95) was used as the reference fuel. The vehicles were equipped with the additional conversion kits. The adjustment of the engine was performed using a programmable control unit. All measurements were performed using static methods. Fuel consumption, engine output and engine efficiency were among the parameters evaluated. The measurement results show the positive impact of ethanol on combustion processes with respect to all engines evaluated. The results also indicate that the adjustment of the engine, more precisely injected amount, has the main influence on the output parameters.

KEYWORDS: STOICHIOMETRIC RATIO, FUEL CONSUMPTION, ENGINE OUTPUT, ENGINE EFFICIENCY

\section{INTRODUCTION}

Due to low oil reserves and major problems with air pollution from exhaust emissions generated during the combustion of fuels made from crude oil, people have started to look for new sources of energy. New fuels are being developed that will maintain the operating parameters of an engine, not significantly pollute the environment, and that can replace conventional fuels. Good examples of such fuels include biofuels, which are liquid or gaseous fuels made of biomass. One of them is bioethanol. The use of ethanol as a fuel for spark-ignition engines has long history. The first use occurred at the end of $19^{\text {th }}$ century due to the lack petroleum fuels. The increasing efficiency of crude oil extraction enabled a gradual replacement of ethanol by gasoline. The use of ethanol-gasoline mixtures ceased in the 1950s. Bioethanol fuel appears again with the approval of Directive 2003/30/EC of the European Parliament and of the Council on 8 May 2003. This directive was created for the promotion of the use of biofuels and 
other renewable fuels for transport, and resulted in the creation of preconditions for a gradual re-introduction and increase in the content of bio-components used in existing conventional fuels. In the Czech Republic, a compulsory addition of $4.1 \%$ of ethanol into gasoline was ordered by Act No. 172/2010 Coll.

Bioethanol belongs to the group of light alcohols and is a product of fermentation processes, which transform raw materials containing biodegradable wastes and residues into utility products [2].

The disadvantage of these lower alcohols is their low heating value and the low volatility at low temperature. The low volatility influences the starting properties of internal combustion engines significantly. Cold starting of the engine is possible only at temperatures above $7{ }^{\circ} \mathrm{C}$ when using pure ethanol. This shortcoming is usually solved in such a way that this fuel is mixed with light hydrocarbons or with gasoline. The cold-start capability is then improved and shifts to the zone of start temperatures below zero. In some countries, the most widespread is the mixture containing $85 \%$ of ethanol and $15 \%$ of gasoline. This mixture is well-known under the trade name biofuel E85 (hereinafter just E85). The low heating value is compensated for by adjusting the stoichiometric ratio. The stoichiometric ratio of gasoline is 1:14.5 but the stoichiometric ratio of E85 is 1:10 (i.e. $10 \mathrm{~kg}$ of air per $1 \mathrm{~kg}$ of fuel) [6]. This change of stoichiometric ratio caused an increase of biofuel consumption at combustion. The other basic properties of biofuel E85 and gasoline (BA95) are stated in the appendices in table 1.

The aim of this study is analysis of the influence of biofuel E85 combustion on engine output parameters, in particular fuel consumption, engine output and engine efficiency. Total engine efficiency (efficiency of fuel chemical energy transformation into mechanical energy) was calculated by means of equation [5]:

$\eta_{e}=\frac{3,6 \cdot P_{e}}{M_{p h} \cdot H_{u}}=\frac{3600}{m_{p e} \cdot H_{u}}[-]$

where: $P_{e}$ - engine output $[\mathrm{kW}], M_{p h}$ - fuel consumption $\left[\mathrm{kg} \cdot \mathrm{h}^{-1}\right]$, $m_{p e}$ - specific fuel consumption [g.kW-1.h-1 $\mathrm{h}^{-1} \mathrm{Hu}$ - net heating value $\left[\mathrm{MJ} . \mathrm{kg}^{-1}\right]$.

According to equation (1), the engine efficiency depends not only on fuel consumption and net heating value, but also on engine output. Net heating value was used from table 1: Basic fuel properties of BA95 and E8 where the net heating value is stated for the fuel temperature $25^{\circ} \mathrm{C}$. The fuel temperatures fluctuated around this level during the measurements.

For the comparison of engine output parameters petrol Natural 95 (hereinafter BA95) was used as a reference fuel

\section{PRACTICAL PART}

The experimental measurements included testing two vehicles and one engine. The vehicles were tested on a chassis dynamometer and the engine was tested in the engine testing laboratory of the Department of Engineering and Automobile Transport of Mendel University in Brno. All measurements were conducted using static methods and at maximum throttle opening (100\%). The measured values were corrected to atmospheric conditions by provisions of the Czech standard ČSN 302008.

\subsection{EXPERIMENTAL MEASUREMENTS ON THE CHASSIS DYNAMOMETER}

\subsubsection{MATERIAL AND METHODS}

The tested vehicles were the Volkswagen Golf 1.4 and 1.6 fourth model series. Technical parameters of the vehicle engines are presented in appendices in Tables 2 and 3. Due to the different mixing ratios of E85 and BA95, it was necessary to modify the supply of injected fuel to ensure the proper course of the combustion process. In both cases the adjustment of control algorithms for engine operation on E85 used additional conversion kits. The engine control unit of these vehicles was combined with a controller, whose internal algorithm extends the period of opening of the injection valve, which modifies the richness of fuel mixture to the desired value. Other regulation algorithms were implemented by the original control system. On the Volkswagen Golf 1.4, the additional controller was made by Europecon, type: Europecon Flex MPI - A4 (Figure 1). The controller of the Volkswagen Golf 1.6 was made by Astes. The controller can work in automatic mode. The adjustment of the opening period of the injection valve depends on the composition of the ethanol-gasoline mixture, which is combusted in the engine at the time.

The measurement of engine parameters was carried out using a chassis dynamometer in the laboratory of the Department of Engineering and Automobile Transport. The power measured by the chassis dynamometer is the power on the wheels. For the purposes of experimental measurement the deceleration test was used. Thanks to the deceleration test the power loss was determined, which was used for the calculation of engine power, according to equation 2 :

$P_{e}=P_{h}+P_{z}[\mathrm{~kW}]$

where: $P_{e}$ - engine power (engine output) $[\mathrm{kW}], P_{h}$ - power on wheels $[\mathrm{kW}], P_{z}$ - power loss [kW] 


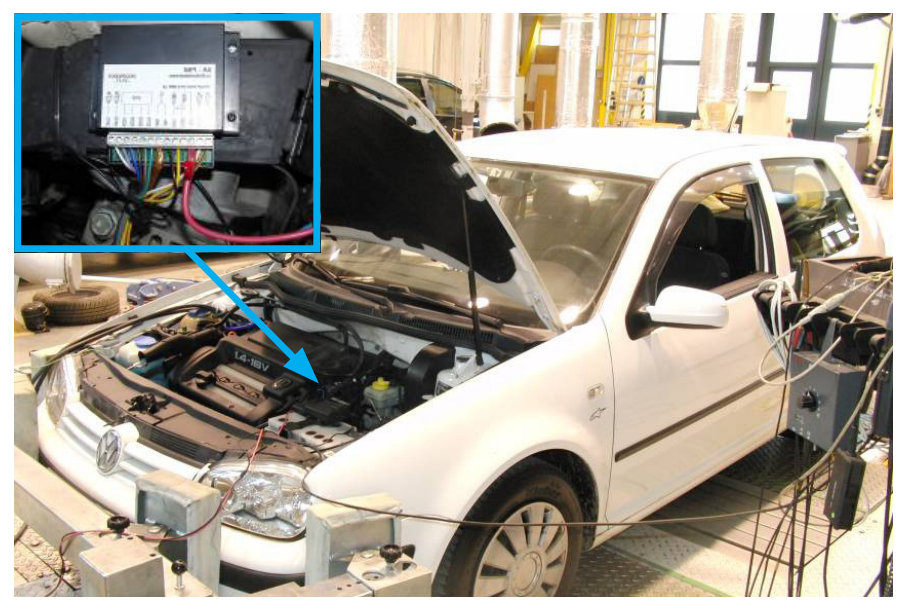

FIGURE 1: Volkswagen Golf 1.4 vehicle on a chassis dynamometer with conversion kit made by Europecon

OBRÁZEK 1: Vozidlo Volkswagen Golf 1.4 na válcovém dynamometru vybavený přestavbovou sadou od společnosti Europecon

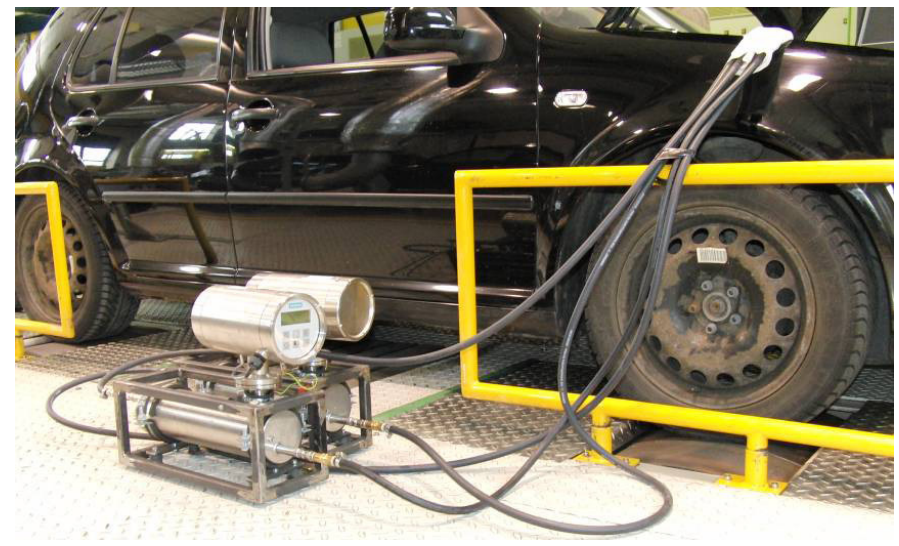

FIGURE 2: Fuel consumption measurement for the Volkswagen Golf 1.6 using mass flow meters Coriolis Sitrans FC MassFlo Mass 6000 OBRÁZZEK 2: Měření spotřeby paliva u vozidla Volkswagen Golf 1.6 pomocí hmotnostních průtokoměrů Coriolis Sitrans FC MassFlo Mass 6000

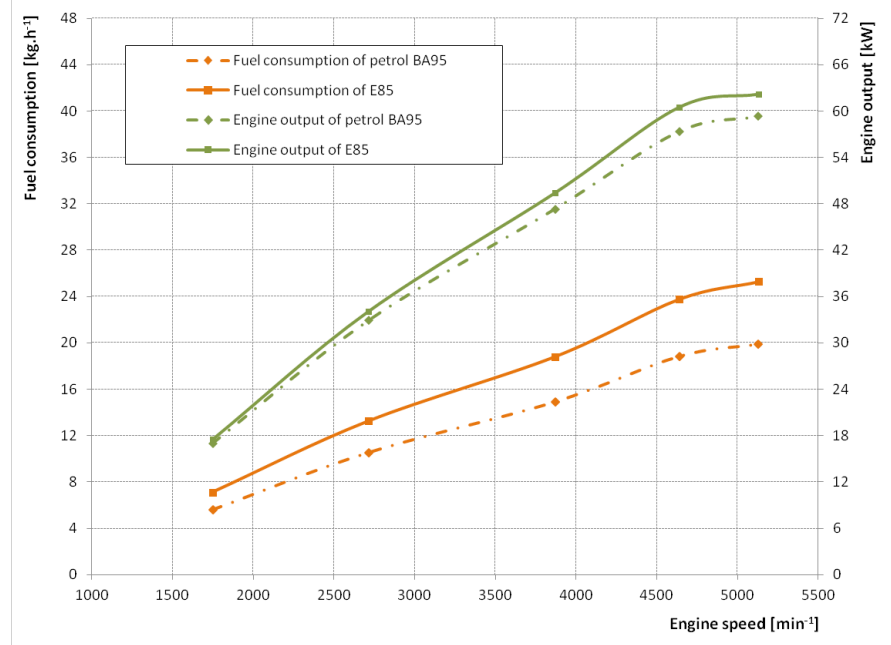

FIGURE 3: Graph of fuel consumption and engine output of the Volkswagen Golf 1.4

OBRÁzEK 3: Průběh spotřeby paliva a výkonu motoru vozidla Volkswagen Golf 1.4
The measurement of fuel consumption was performed using two differentially connected mass flow meters Coriolis Sitrans FC MassFlo Mass 6000 (Figure 2).

Repeat measurements were performed over three subsequent tests. The coefficient of variation did not exceed $2 \%$ for each monitored parameter.

\subsubsection{RESULTS}

The main recorded parameters were fuel consumption and engine output. Specific fuel consumption was calculated from these parameters, which was used for the calculation of engine efficiency using equation (1). Lambda was also one of the recorded parameters. When we ran the Volkswagen Golf 1.4 engine on BA95, lambda was $\lambda=0.81$. In the case of biofuel E85 the value of lambda was $\lambda=0.99$. If lambda exceeds the value of 1 at high engine speed, there is a risk of a temperature increase in the combustion chamber, thus a possibility of thermo-mechanical engine damage. When the rich mixture $(\lambda<1)$ is combusted, it comes to the internal cooling of the combustion chamber. E85 has a considerable advantage in having double the value of latent heat of vaporization and therefore better cooling of the combustion chamber in the cylinder at charge exchange (latent heat of vaporization of E85 is $923 \mathrm{~kJ}^{\mathrm{kg}}{ }^{-1}$, compared

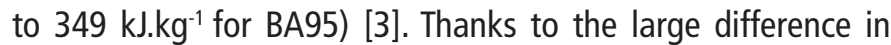
richness of the mixture there was not the large increase in fuel consumption that could be expected. Hourly fuel consumption of E85 was only $16 \%$ higher compared to BA95 at maximum torque (if we take the calculation of fuel as a base) (figure 3). The maximum torque was reached by the engine at 3640 RPM. As compared with BA95, the increase in engine output with the controller Europecon Flex MPI - A4 was slight $(+0.5 \mathrm{~kW}$ at maximum torque).

By converting fuel economy $\left[\mathrm{kg} \cdot \mathrm{h}^{-1}\right]$ per unit $\left[\mathrm{MJ} \cdot \mathrm{kW}^{-1} \cdot \mathrm{h}^{-1}\right]$, we get the amount of energy included in the fuel that is needed to produce $1 \mathrm{~kW}$ of engine output. The amount of energy that was necessary to produce $1 \mathrm{~kW}$ of engine output with E85 at the maximum engine torque was $10.6 \mathrm{MJ}^{-1} \mathrm{~h}^{-1}$, with gasoline BA95 it was $13.4 \mathrm{MJ} \cdot \mathrm{h}^{-1}$. According to equation (1) we can conclude that the cycle efficiency is higher for E85 than for gasoline. Figure 4 shows the relationship between calculated values of engine efficiency and RPM for both fuels. The measured points were interposed by polynomial interpolation. We can see a significant difference in achieved engine efficiency. The calculated efficiency achieved was $33.9 \%$ for E85 and $26.8 \%$ for BA95 at maximum torque.

In Figure 5, plots of fuel consumption and engine output of the Volkswagen Golf 1.6 are presented. Maximum torque of the engine was reached at $4640 \mathrm{RPM}$. The lambda value was $\lambda=0.90$ when the engine was running on BA95. When we operated the

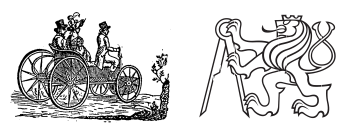




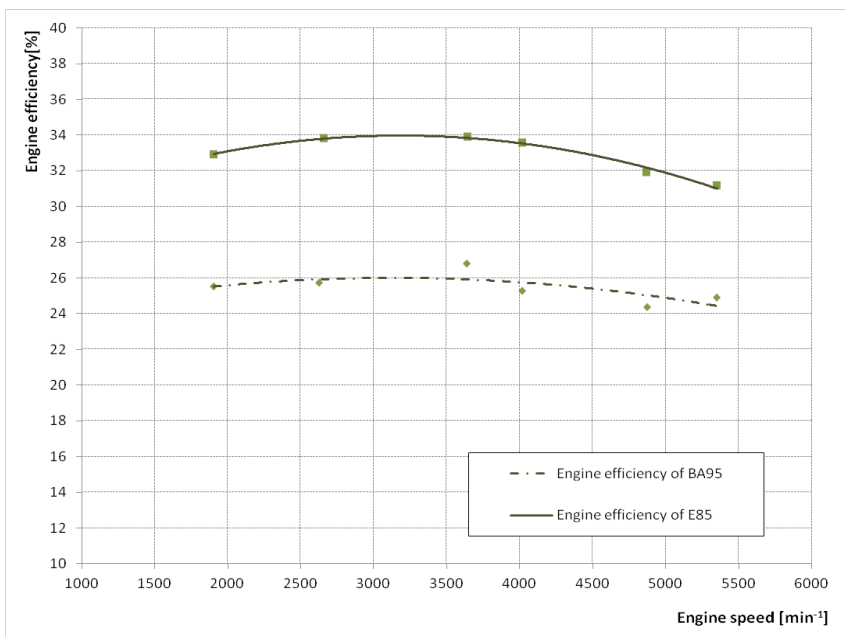

FIGURE 4: Graph of engine efficiency of the Volkswagen Golf 1.4 OBRÁZEK 4: Průběh účinnosti motoru vozidla Volkswagen Golf 1.4

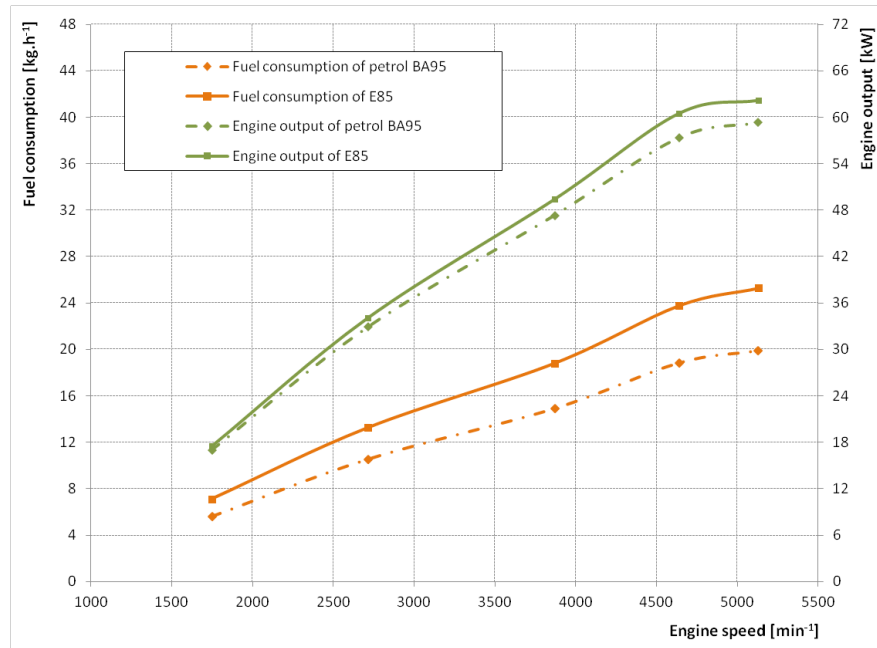

FIGURE 5: Plots of fuel consumption and engine output for the Volkswagen Golf 1.6

OBRÁZEK 5: Průběh spotřeby paliva a výkonu motoru vozidla Volkswagen Golf 1.6

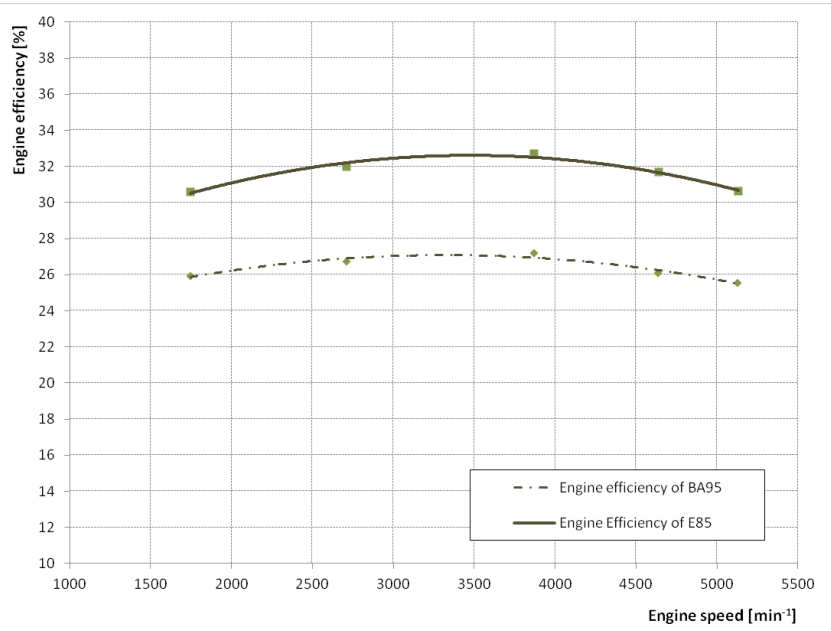

FIGURE 6: Plots of engine efficiency for the Volkswagen Golf 1.6 OBRÁZEK 6: Průběh účinnosti motoru vozidla Volkswagen Golf 1.6 engine on $\mathrm{E} 85$, the lambda was adjusted by conversion kits to the value $\lambda=0.94$ at maximum torque. The difference in lambda is lower for the Volkswagen Golf 1.4. Therefore the increase in E85 fuel consumption was $26.3 \%$ higher compared to gasoline at maximum torque. At the same time, when we operated the engine on $\mathrm{E} 85$, the engine output was higher. The increase was by $3.2 \mathrm{~kW}$ (Figure 5). The calculated engine efficiency was $31.7 \%$ for E85 and only $26.1 \%$ for BA95 (Figure 6).

\subsection{EXPERIMENTAL TESTING ON ENGINE TEST RIG}

\subsubsection{MATERIAL AND METHODS}

The last engine for experimental measurement was a Peugeot PRV6 spark-ignition engine. Technical parameters of the engine are presented in the appendices in Table 4.

The modification of the supply of injected fuel was adjusted with the programmable control unit. Before this, due to a lack of flow characteristics of the injection valve at high engine speeds we had to increase fuel pressure from $0.3 \mathrm{MPa}$ to $0.5 \mathrm{MPa}$. In the next step, the adjustment of the engine was followed by the programmable control unit. The programmable control unit was manufactured by the Magneti Marelli. The adjustment values involved only the amount of fuel injected into the cylinder at given values of RPM. The supply of both BA95 and E85 was adjusted in such a way that the engine operated with the same air surplus coefficient. Other control values (e.g. the spark advance setting) remained unchanged and were the same as those for the engine combusting BA95 as well on the tested vehicles. Figure 7 shows the modified fuel map for biofuel E85.

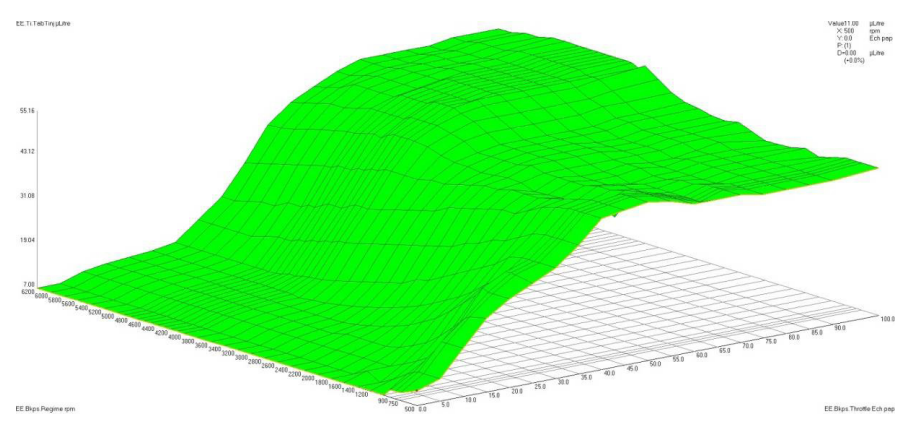

FIGURE 7: Modified fuel map for biofuel E85 combustion OBRÁZEK 7: Upravená palivová mapa pro spalování biopaliva E85

The experimental measurement of engine operating parameters (torque, fuel consumption, etc.) was also carried out at $100 \%$ throttle. The engine loading took place from 6000 RPM to 1500 RPM. The engine was loaded using an Alpha 240 eddy current dynamometer made by AVL. The measurement of fuel consumption was performed using Coriolis Sitrans FC MassFlo Mass 6000 mass flow meters as well as in case of the vehicle mounted engine. 


\subsubsection{RESULTS}

The recorded parameters were the same as for the vehicle engines. The results of measurements (figure 9) indicate that in the engine combusting E85 its fuel consumption gradually increased. At 100\% throttle opening, fuel consumption for $\mathrm{E} 85$ is about $36 \%$ higher at maximum torque (if we take the calculation of fuel as a base). Maximum torque was reached at 4000 RPM. At this point, the engine output increased by $5.5 \mathrm{~kW}$ in the case of $\mathrm{E} 85$ combustion.

Engine efficiency for BA95 gasoline fluctuated around 30.65\% and for biofuel E85 $34.26 \%$. The values were also achieved at maximum torque. From figure 10 we can see that the difference in achieved efficiencies increases with the revolutions. This is caused by the increased difference in engine output (figure 9).

\section{DISCUSSION}

The results of various studies $[3,4]$ show the positive effect of biofuel E85 combustion on engine output and efficiency. This is also confirmed by the results we achieved. Figure 5 compares results of output parameters for all engines tested. Apart from the chemical properties of both fuels, particularly its net heating value, the fuel consumption and engine output also influence the efficiency of an internal combustion engine. Extension of the period of opening of the injection valve is important due to the different mixing ratios of the $\mathrm{E} 85$ combustion compared to BA95 combustion. When the engine is operated with the same period of opening of the injection valve, the engine output could drop and at high engine speeds, thermo-mechanical damage could occur. On the other hand, an excessive increase in the mixture richness below the value $\lambda=1$ leads to increased engine power, but the efficiency of the combustion cycle decreases, as seen on the Peugeot engine. The Peugeot engine was operated with the same lambda value for both fuels. The average increase in fuel consumption is by $32.2 \%$ at the average engine output increase of $3.2 \mathrm{~kW}$. The total difference in engine efficiency is lower, only $3 \%$. The biggest difference in engine efficiency was achieved by the Volkswagen Golf 1.4 (Figure 11), which was equipped with the Europecon controller. The controller maintained the value of lambda around $\lambda=0.99$ for E85 combustion, and lambda $\lambda=0.81$ when running on BA95. When the vehicle was operating on biofuel E85, the increase in engine output was slight.

The results of our experimental measurements correspond to the results recorded by Schifter et al [7]. Their study shows that with increasing proportion of ethanol in a mixture with petrol, the proportion of released heat made from combustion of injected fuel increases as well. More heat can then be transformed into mechanical work. The mixtures containing ethanol burn faster than the petrol without ethanol. All these properties have a direct impact on engine output parameters and overall engine efficiency.

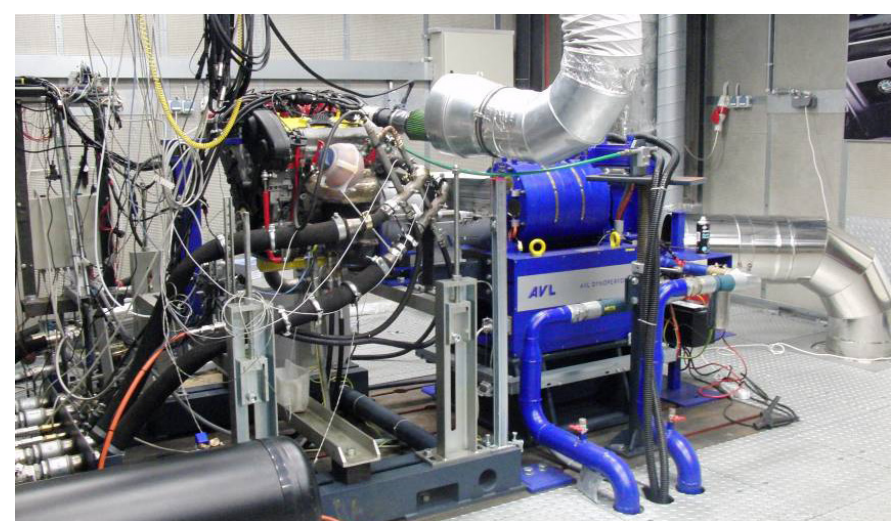

FIGURE 8: Laboratory of the engine testing station of the Department of Engineering and Automobile Transport, 1 - tested engine Peugeot PRV V6, 2 - eddy current dynamometer AVL Alpha 240 OBRÁzEK 8: Laboratoř zkušebny motorů na Ústavu techniky a automobilové dopravy, 1 - testovaný motor Peugeot PRV V6, 2 elektricky viŕivý dynamometr AVL Alpha 240

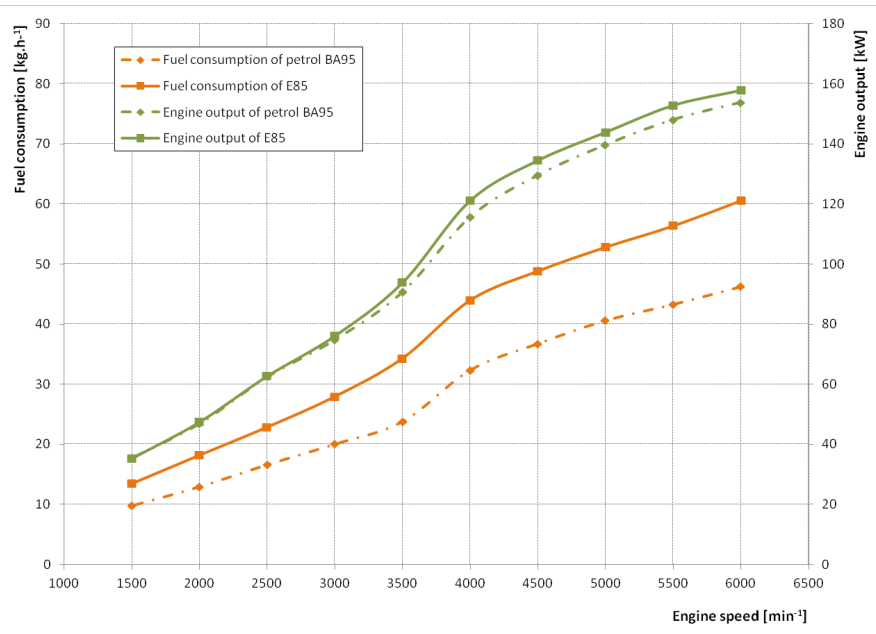

FIGURE 9: Plots of fuel consumption and engine output of the Peugeot PRV V6 engine

OBRÁZEK 9: Průběh spotřeby paliva a výkonu motoru Peugeot PRV V6

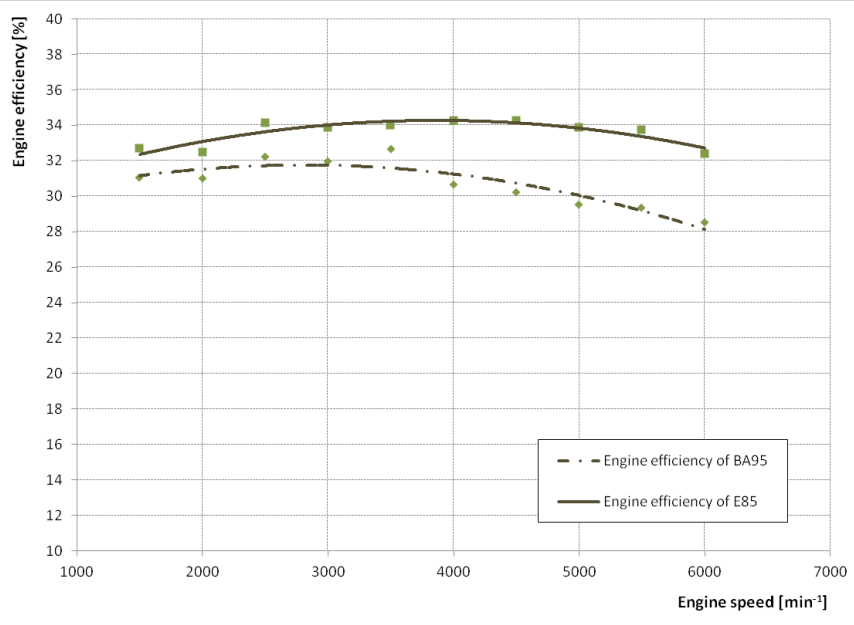

FIGURE 10: Plots of engine efficiency of the Peugeot PRV V6 engine OBRÁZEK 10: Průběh účinnosti motoru Peugeot PRV V6 engine 


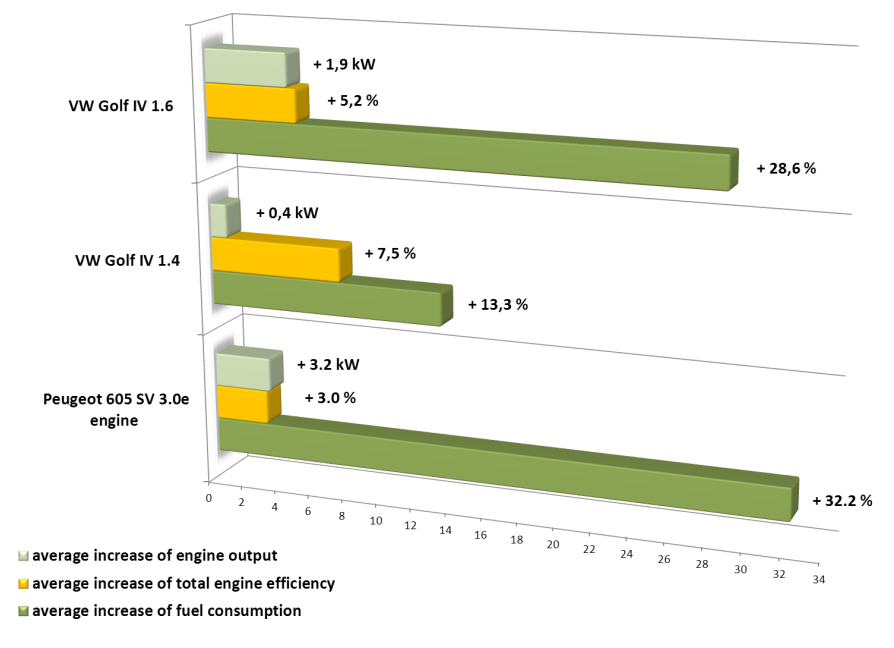

FIGURE 11: Comparison of engine outputs of the tested vehicles and engine FIGURE 11: Porovnání výstupních parametrů testovaných vozidel a motoru

\section{CONCLUSION}

The experimental measurements were focused on monitoring the impact of biofuel E85 combustion on engine output parameters. For objective assessment of its impact, the measurement of two vehicles was carried out with the help of a chassis dynamometer, and of an engine with the help of an eddy current dynamometer. Due to the different properties of ethanol compared to gasoline, in particular heating value, the mixing ratio of $\mathrm{E} 85$ and air had to be adjusted before the measurements. Other control values remained unchanged and were the same as those of the engine combusting BA95. The measurement results show the positive effect of ethanol on the engine output and efficiency. The engine efficiency was calculated from the net heating value, its fuel consumption and engine output using equation (1). Based on the results, we conclude that the smaller the increases in fuel consumption to achieve the required mixing ratio, the greater is the effect on engine efficiency of using biofuel E85. As these results show, the adjustment of the engine, or more precisely the injected amount, has the main influence on the output parameters.

Thanks to other favourable chemical properties of ethanol, especially higher octane number, the optimization of the combustion process would not only include the change of mixing ratio, but also the adjustment of spark advance. At present there are also several producers of so called FFV vehicles (Flexible Fuel Vehicle). These vehicles can automatically adjust to the richness of the mixture, ignition timing, pressure, performance, etc., depending on the proportion of ethanol and gasoline in the tank.

\section{ACKNOWLEDGEMENTS}

This work was part of the project DOPSIT Reg.

No. CZ.1.07/2.3.00/20.0226 funded under the Operational Program Education for Competitiveness and was supported by the project of Internal Grant Agency of Mendel University in Brno, TP2/2012 "Implementation of network protocol based on SAE J1939 recommendation into agricultural tractor" as well.

\section{REFERENCES}

[1] Aleiferis P. G., Serras-Ppereira J., Romunde Z., Caine J. and Wirth M. (2010). Mechanisms of spray formation and combustion from a multi-hole injector with $\mathrm{E} 85$ and gasoline. In Combustion and Flame, Vol. 157, pp. 735-756.

[2] Demibras A. Biofuels. Green Energy and Technology. Springer, London, 2009, 336 p. ISBN 978-1-84882-010-4

[3] Karavalakis G., Durbin T. D., Shrivastava M., Zheng Z., Villela M., Jung H. (2012). Impacts of ethanol fuel level on emissions of regulated and unregulated pollutants from a fleet of gasoline light-duty vehicles. Fuel, Vol. 99, pp. 549-558.

[4] Koc M., Sekmen Y., Topgül T., Yücesu S. H. (2009). The effects of ethanol-unleaded gasoline blends on engine performance and exhaust emissions in a spark-ignition engine. Renewable Energy, Vol. 34, pp. 2101-2106.

[5] Macek J., Suk B. Spalovací motory I, ČVUT, Praha, 1996, 242 p. ISBN 80-01-00919-X

[6] Park S. H., Kim J. K., Suh H. K., Lee CH. S. (2009). Atomization and spray characteristics of bioethanol and bioethanol blended gasoline fuel injected through a direct injection gasoline injector. International Journal of Heat and Fluid Flow, Vol. 30, pp. 1183-1192.

[7] Schifter I., Diaz L., Rodriguez R., Gómez J. P., Gonzales U. (2011). Combustion and emissions behavior for ethanol-gasoline blends in a single cylinder engine. Fuel, Vol. 90, pp. 3586-3592.

\section{APPENDICES}

TABLE 1: Basic fuel properties of BA95 and E85 [1]

TABULKA 1: Základní vlastnosti paliva BA95 a E85 [1]

\begin{tabular}{lcc}
\hline Fuel properties & Gasoline (BA95) & E85 \\
\hline Density $\left(\mathrm{kg} \cdot \mathrm{m}^{-3}\right)$ & 752 & 784 \\
\hline Heating value at $25^{\circ} \mathrm{C}(\mathrm{MJ} . \mathrm{kg})$ & $42-45$ & 28,94 \\
\hline Boiling point $\left({ }^{\circ} \mathrm{C}\right)$ & $30-190$ & 84,8 \\
\hline Reid vapour pressure $(\mathrm{kPa})$ & $54-60$ & 53,6 \\
\hline Research Octane Number $(\mathrm{RON})$ & 95 & 109,1 \\
\hline $\mathrm{H}: \mathrm{C}$ & $1,86-1,92$ & 2,657 \\
O:C & 0 & 0,411
\end{tabular}


TABLE 2: Technical parameters of testing vehicle VW Golf 1.4 engine TABULKA 2: Technické parametry motoru testovaného vozidla VW Golf 1.4

\begin{tabular}{lc}
\hline Parameter & Specification \\
\hline Engine volume & $1,390 \mathrm{~cm}^{3}$ \\
\hline Maximal engine output & $55 \mathrm{~kW}$ at $5000 \mathrm{RPM}$ \\
\hline Maximal torque & $126 \mathrm{~N} . \mathrm{m}$ at $3300 \mathrm{RPM}$ \\
\hline Bore & $76.5 \mathrm{~mm}$ \\
\hline Stroke & $75.6 \mathrm{~mm}$ \\
\hline Compression ratio & 10.5 \\
\hline
\end{tabular}

TABLE 3: Technical parameters of testing vehicle VW Golf 1.6 engine TABULKA 3: Technické parametry motoru testovaného vozidla VW Golf 1.6

\begin{tabular}{lc}
\hline Parameter & Specification \\
\hline Engine volume & $1,598 \mathrm{~cm}^{3}$ \\
\hline Maximal engine output & $77 \mathrm{~kW}$ at $5700 \mathrm{RPM}$ \\
\hline Maximal torque & $148 \mathrm{~N} . \mathrm{m}$ at $4500 \mathrm{RPM}$ \\
\hline Bore & $76.5 \mathrm{~mm}$ \\
\hline Stroke & $86.9 \mathrm{~mm}$ \\
\hline Compression ratio & 11.5 \\
\hline
\end{tabular}

TABLE 4: Parameters of testing engine Peugeot PRV V6

TABULLKA 4: Technické parametry testovaného motoru Peugeot PRV V6

\begin{tabular}{lc}
\hline Parameter & \multicolumn{1}{c}{ Specification } \\
\hline Make & Peugeot \\
\hline Model & 605 SV 3.0e PRV V6 \\
\hline Engine output & $142.6 \mathrm{~kW}$ at 5,500 RPM \\
\hline Engine volume & $2,946 \mathrm{~cm}^{3}$ \\
\hline Bore x stroke & $87.0 \times 82.6 \mathrm{~mm}$ \\
\hline Compression ratio & 9.5 \\
\hline Number of cylinders & 6 \\
\hline Injection system & Indirect multi-hole injection \\
\hline
\end{tabular}
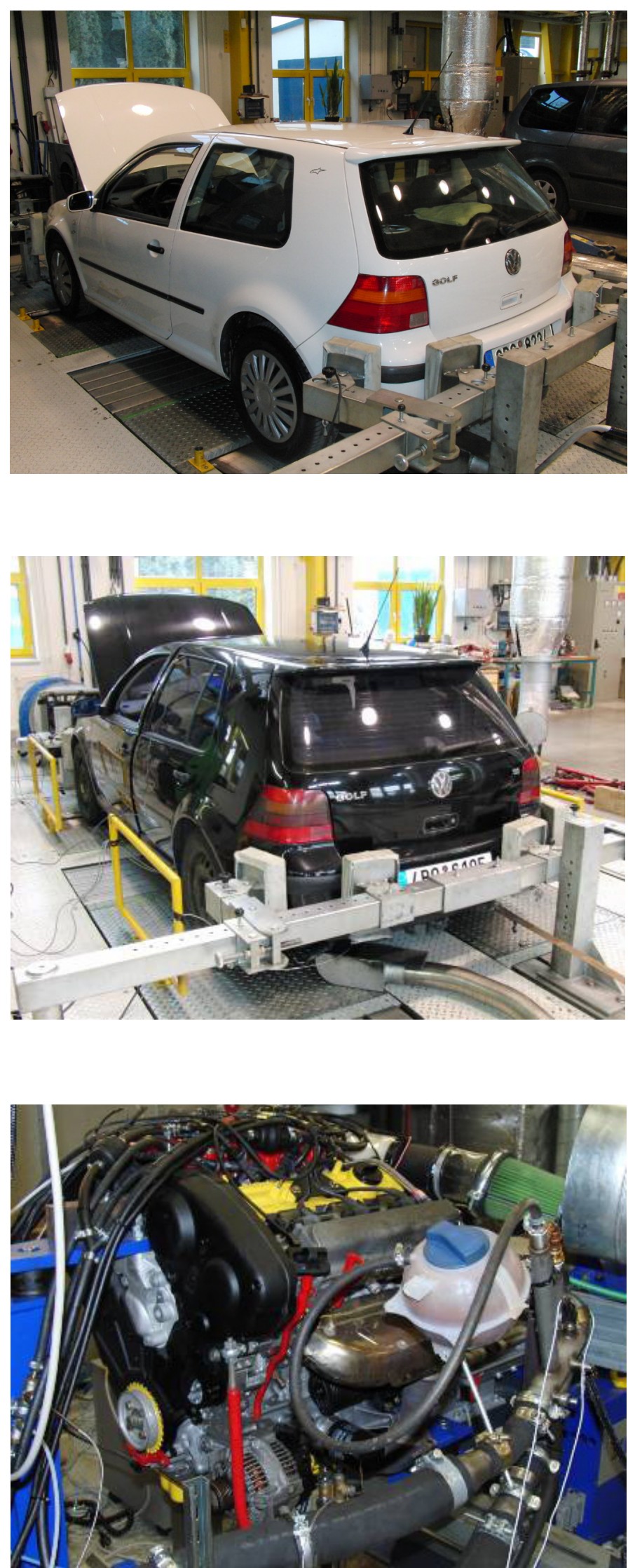